\title{
Social Media Usage Patterns of Turkish Maritime Businesses: A study on Facebook
}

\author{
Fatma Özge BARUÖNÜ, Özlem SANRI \\ Doğus University, Department of International Trade and Business, Turkey \\ olatif@dogus.edu.tr; ORCID ID: https://orcid.org/0000-0001-5533-775X \\ osanri@dogus.edu.tr; ORCID ID: https://orcid.org/0000-0002-9788-6594
}

\begin{abstract}
Social media has been widely used by businesses nowadays. Although in B2B industry, social media marketing isn't grown up as fast as it was in B2C market, many businesses begun to develop social media strategies and reach to new and existing corporate customers via social media recently. In this study, the main purpose is to examine social media usage patterns of Turkish maritime transportation companies through Facebook. In order to identify the social media usage habits of Turkish maritime transportation companies an exploratory study was conducted. In the period between January-November 2018, the maritime companies existing in Facebook are analyzed with a content analysis in terms of contents of the posts and stakeholder engagement levels. The findings show that posts on corporate image and special days are highly re-shared and taken positive reactions by followers. At the end of the study, suggestions for practitioners and direction for further studies are presented.
\end{abstract}

Keywords: Maritime Business, Facebook, Social Media, Engagement, Stakeholder Approach.

\section{Denizcilik İşletmelerinde Sosyal Medya Kullanım Modelleri: Facebook Üzerine Bir Çalışma}

Öz

Günümüzde işletmeler tarafindan sosyal medya yoğun olarak kullanılmaktadır. Her ne kadar B2B pazarında sosyal medya pazarlaması B2C pazarına göre daha hızlı büyümese de, çoğu işletme son günlerde sosyal medya stratejilerini geliștirmeye ve yeni ve mevcut kurumsal müșterilerine sosyal medya ile ulașmaya başlamıștır. Bu çalışma Türkiye'de yer alan denizcilik işletmelerinin sosyal medya kullanım șekillerini Facebook üzerinden incelemeyi amaçlamıștır. Türk deniz taşımacılığı şirketlerinin sosyal medya kullanım alışkanlıklarını belirlemek amacıyla keşifsel bir araştırma yapılmıştır. Ocak-Kasım 2018 dönemleri içerisinde Facebook hesabı olan denizcilik işletmeleri, gönderilerinin içerikleri ve paydaş katılımı seviyeleri açısından içerikanaliziyöntemi ile analiz edilmiştir. Bulgular, kurumsal imajveözelgünlergönderilerininyüksekoranda yeniden paylaşıldığını ve takipçiler tarafindan bu gönderilere olumlu tepkiler verildiğini göstermektedir. Çalışmanın sonucunda, uzmanlara yönelik önerilere ve ileriki çalışmalar için yönlendirmelere yer verilmiștir.

Anahtar Kelimeler: Denizcilik Işsletmeleri, Facebook, Sosyal Medya Etkileșimi, Paydaş Yaklaşımı. 


\section{Introduction}

In $\mathrm{B} 2 \mathrm{~B}$ marketing, the companies are operating in a highly competitive environment though marketing communication tools have critical importance [1]. In order to create and share rich, interactive, fast and customized contents, the professionals in B2B market have benefit social media with the rising of Web 2.0. [2]. Today social media has become one of the most important parts of any digital marketing strategy [3]. Mangold and Faulds [4] offered social media as a hybrid component of the promotional mix and as an integral part of the businesses' integrated marketing communications strategy. For a sustainable profit having a web site is not adequate thus companies are now focused to achieve relational exchanges with their customers therefore social media is the key for B2B companies to be closer to their potential and existing customers.

Shipping in a highly competitive environment is an international industry by nature. Nearly more than $85 \%$ of world's international trade is carried by maritime transportation. Global seaborne trade in 2017 has been reached to 10,7 billion tons with a \%4 annual growth which can be explained as the fastest growth in five years [5]. Thus, shipping companies' services are produced to satisfy the derived demand for the transport of cargoes. Maritime transportation firms are serving to other businesses and their main focus is to cut their costs while satisfying their customers. When doing this, they are neglecting to allocate their financial resources for marketing campaigns or advertisements in order to improve their brand images and brand values [6]. However, the benefits of marketing efforts, in particular utilizing social media is quite important for many B2B companies to enhance their brand awareness and brand image.

The aim of the study is enhancing our understanding on social media usage of maritime transportation companies which are one of the biggest players of B2B service industry. In B2C market social media and its benefits for businesses has taken too much attention by far, however role of social media in $\mathrm{B} 2 \mathrm{~B}$ market is quite new and fruitful research area. Recent researches put attention to investigate the social media usage in maritime industry newly. However, this research will be the first for identifying Turkish maritime transportation companies' Facebook usage by adopting stakeholder engagement index which will be a contribution for Turkish maritime transportation practitioners to improve their social media pages.

The rest of the paper is organized as follows. A literature review on social media usage habits in maritime shipping industry was employed. Then an exploratory research was conducted to understand the social media usage patterns of Turkish maritime transportation companies through content analysis technique. Stakeholders engagement matrix which was developed by Bonson and Ratkai (2013) was used to measure popularity, commitment and virality of maritime transportation companies' Facebook accounts. Finally, suggestions to increase the power and collaborative functions of social media platforms, theoretical and managerial implications were discussed in conclusion part.

\section{Social Media}

Social media has enabled the communication as many-to-many [7]. which means that audience in social media interacts both with the companies and customers [4]. Therefore, while planning communication in social media, it is important to reshape of communication by identifying how messages are created, composed, disseminated and consumed [8] and producing contents which have high 
potential to have been reed and shared by the followers.

The general perception of B2B marketers was that social media wouldn't serve potential to B2B companies, even it is an irrelevant platform to connect their customers [9]. Due to the nature of B2B companies, marketers think that purchasing process requires face-to-face interaction [10]. One of the reason behind this thought is the lack of understanding how to do so, and perceived benefits [11]. Over time, this opinion was left and B2B companies try to have an existence in social platforms to be more visible. Although these companies don't expect to take order through social media, they remark that they can benefit from the advantages of social platforms. North Venture Partners [12] distinguish the areas where B2B companies could use social media effectively: public relations, customer service, market research, brand marketing, promotion, consumer education, sales, product expansion, and customer relationship management. The main aim is to "get closer to the customers", while getting the attention of press, gaining higher employee engagement and developing more brand awareness. Users and followers of B2B social media include employees of companies, customers, industry experts, and business partners or suppliers. According to Forrester Research, such people use social media platforms for both consumption of information/ news and interaction [13].

On the other hand, in the literature the academics has directed theirresearch on B2C companies' social media marketing efforts and strategies and has provided results regarding positive and negative returns to companies by far [14]. Researchers began to put attention to understand social media communication for B2B business only for a couple of years. Walters [15] argued that B2B organisations can also benefit from social media they are able to follow three strategies which are; information rich strategy, relational exchange and joint learning. Balmer and Low [16] and Brennan and Croft [17] explored the issue from branding side, Mehmet and Clarke [18] analysed social media semantics for B2B. Jarvinen et al [9] and Michaelidou et al. [11] studied on social media metrics for industrial firms. Siamagka et al. [19] defined the factors affecting the adoption of social media in B2B organisations. Andersson and Wikström [20] investigated why and how B2B companies use social media. In their research they found out that B2B companies increased their customer relationship, strengthened the brand and support sales by using social media.

Frequently-used social media platforms can be listed as Facebook, LinkedIn, Twitter, YouTube, and Instagram [21]. Companies and customers interact with different B2B social media platforms in different ways [20]. Facebook is the oldest and most popular platform among the all social media tools therefore it has the most members compared with others. There are successful marketing practices in terms of usage of Facebook accounts.

\section{Marketing and Stakeholder Approach}

To understand social media usage in B2B context, stakeholder theory was frequently benefitted from. Stakeholder view defines organisations as a grouping of stakeholders and stresses the importance of managing different stakeholders' interest [22]. For maritime transportation companies in order to successfully manage the relationships with the stakeholders it is vital to know how to communicate with them that includes customers, employees, shareholders, regulators and investors [20].

Bruce and Shelly [23] define stakeholder engagement as the interaction among the individuals and groups who involve in a corporation. From the external customer perspective, social media provide product 
and process info, enhance brand image and corporate image, deliver advertisements, help to improve customer relationship management and after sales services. From the internal customer perspective, it can be used for announcing the vacant positions, honour the staff and strength the internal relations. From the community perspective, company can share special messages and announce social responsibility campaigns.

There are different ways of measuring social media efficiency. One of them has three parts; volume - how many people talk, influence - who talks, and sentiment - what people talk. Number of friends on company's profile, number of likes, number of comments and shares are the frequently used scales to measure the success of a social media tool. Also, tone of users comments (positive, neutral, negative) show the reflections of the customers [24]. Maersk Line's managers measured engagement on Facebook by a formula where they take a sample of their latest 10 posts, added up the likes, number of comments and shares. This total value is compared to other values that other multinational brands have. On the other hand, measuring the direct effects of social media on B2B companies is very tough $[11,25]$.

With the aim of creating brand awareness and positive attitude to their company maritime transportation companies begin to apply communication strategies through social media. As Facebook is the oldest social media platform and number of users exceed millions, maritime transportation companies first open a page with their brand name. Maersk Line is a good example that use the photos of its ships by combining them with interesting stories. Even they posted a photo with a giraffe on a container ship and took the attention of their fans. In this process the employees also help the company by sharing these posts. Today Maersk Line reach to over 2 million funs in Facebook [13]. In general, Facebook gives opportunities to users to connect with their followers in a visual and conversational structure.

Over time, companies spread to other media like Twitter, Instagram and LinkedIn and also they keep to post in Facebook at the same time. Twitter posts are mostly a mix of more serious news than the Facebook page (retweets from employees, photos, and announcement). Twitter audience include the trade press, shipping professionals, customers, and employees and the Twitter user is 10 times more influential than an average Facebook user [13]. LinkedIn is the most corporate platform and the tone of voice was "more corporate. The LinkedIn page also had several tabs, and enable to listen customers and discuss with them. Instagram is known with the facility of publishing high quality photos and filter effects. Indeed, it is more than it. Hashtags let the companies to create topics and inspire the people taking photos about their business process and share them with their own network.

All these platforms not only increase the brand awareness and provide visibility but also they serve as customer service. Many fans and followers voluntarily defence the firm when they saw a negative comment on the page before the official customer services take action [25]. According to Gorry and Westbrook [25] some companies have already integrated feedback into their organisational processes.

In terms of measuring the stakeholder engagement, in the literature, stakeholder engagement metrics were used to analyze social media usage of several sectors including university libraries, tourism, municipilaties, sports organizations (football and basketball teams), companies which are listed in Carbon Disclosure Project, third-party logistics companies, women entrepreneurs, banks, public transportation agencies, political parties, fashion retailers, telecommunications 
sector and museums. The populations searched in the previous studies were generally belong to $\mathrm{B} 2 \mathrm{C}$ arena which shows the lack of researches in business to business sectors.

Manetti et al. (2016) analyzed stakeholder engagement in Canadian and American public transportation agencies. They applied stakeholder engagement metrics to 33 transportation agencies. Their results show that public transportation agencies use social media in order to present their activities to public. Facebook is the most popular platform for interaction with stakeholders, on the other hand Twitter usage is mostly focused on contents about public information [26]. In B2B sector Sürücü and Şakar (2018) examined the relationship of Turkish logistics service providers with their stakeholders by stakeholder engagement metrics. The findings show that Turkish logistics service providers utilize Facebook as a communication and engagement channel [27]. Metushi and Fradeani (2019) analyzed 200 Albanian companies social media reporting practices by focusing on contents shared by the companies on their Facebook, Twitter and Linkedin pages. The findings reveal that Facebook is the most preferred social media platform. The main focus for using social media is marketing activities [28]. As there is scant research in adopting social media engagement in maritime context it is aimed to understand usage habits of Facebook by maritime transportation companies.

\section{Methodology}

An exploratory study was conducted to understand the social media usage habits of maritime shipping firms in Turkey. Therefore, a content analysis was employed by investigating the social media accounts of all maritime transportation companies in Turkey. Content analysis is a widely used qualitative research technique [29].
As methodology, stakeholder engagement metric is applied which is developed by Bonson and Ratkai (2013) to calculate the index values [30]. This metrics which could be obtained through the publicly available data are shown in Table 1.

The following steps has been taken to identify these companies; first a full list of maritime transportation companies were provided from UTIKAD (Association of International Forwarding and Logistics Service Providers) (September,2018). Although there are 458 members, the list is limited only with maritime transportation companies. Airway, railway, road transportation companies are eliminated. Thus, the population consists of 160 companies. Sampling method of the study is purposeful sampling because, only the companies posted more than 5 posts in their page by far are included to the sample. Therefore sample size is defined as 15. Next, posts are classified in 4 categories depending on their subject by authors. Main topics were determined as, a) special days/events/occasions, b) corporate image, c)sectoral news and d) announcements. For each company, the contents of all the Facebook posts are examined by two researchers who made their own judgements for classification of the contents. To enable inter-coder reliability, Cohen's Kappa value was calculated and found to be varied between $0,90-1,00$ which is exceed the threshold $(0,75)$.

For each category engagement statistics (number of followers, likes, comments and shares) were reported. Number of followers and number of likes are counted for all times whereas likes and shares are only accounted for the period of JanuarySeptember 2018. Comments of followers (if available) are also analysed and categorised. (1) popularity; (2) commitment; and (3) virality were used to measure stakeholder engagement [30]. Popularity is related to 
the number of likes whereas commitment is involved to number of comments. Virality is measured with the help of number of shares. Items of each measure is listed in Table 1. Both quantitatively and qualitatively stakeholders' mood were analyzed. Negative conversations (also understood as negative feedback) are the main reasons for some companies to avoid from social media [31]. news about the company or employees, success stories and social responsibility projects supporting by them. This category is labelled as "corporate image". $1 \%$ of the all posts are about sectoral news, new regulations and information like launching of a new port, changing export taxes etc. and these posts are labelled as "sectoral news", finally $4 \%$ of the posts make the announcements about fairs or events the

Table 1. Metrics for Stakeholder Engagement

\begin{tabular}{|c|c|c|c|}
\hline & Sign & Formula & Measures \\
\hline \multirow[t]{3}{*}{ Popularity } & $\mathrm{P} 1$ & Number of posts with likes/total posts & $\begin{array}{l}\text { Percentage of the total posts that have } \\
\text { been liked }\end{array}$ \\
\hline & $\mathrm{P} 2$ & Total likes/total number of posts & Average number of likes per post \\
\hline & P3 & $(\mathrm{P} 2 /$ number of fans) $* 1,000$ & Popularity of messages among fans \\
\hline \multirow[t]{3}{*}{ Commitment } & $\mathrm{C} 1$ & $\begin{array}{l}\text { Number of posts with comments/total } \\
\text { posts }\end{array}$ & $\begin{array}{l}\text { Percentage of the total posts that have } \\
\text { been commented on }\end{array}$ \\
\hline & $\mathrm{C} 2$ & Total comments/total posts & Average number of comments per post \\
\hline & $\mathrm{C} 3$ & $(\mathrm{C} 2 /$ number of fans $) * 1,000$ & Commitment of fans \\
\hline \multirow[t]{3}{*}{ Virality } & V1 & $\begin{array}{l}\text { Number of posts with shares/total } \\
\text { posts }\end{array}$ & $\begin{array}{l}\text { Percentage of the total posts that have } \\
\text { been shared }\end{array}$ \\
\hline & $\mathrm{V} 2$ & Total shares /total posts & Average number of shares per post \\
\hline & V3 & (V2/number of fans) $* 1,000$ & Virality of messages among fans \\
\hline \multicolumn{4}{|c|}{ Stakeholder Engagement Index (E) } \\
\hline
\end{tabular}

\section{Kaynak: [30]}

\section{Findings}

Out of 160 maritime shipping companies only 43 businesses have a local Facebook page, but 16 of these companies are inactive as they have never posted anything on their page by far. $21 \%$ of the companies posts only 1 to 5 posts, $21 \%$ of them posts $6-29$ posts, $16 \%$ have $30-100$ posts and $5 \%$ add over 100 posts through the year.

$19 \%$ of the companies' posts are related to the special days, events and occasions like Mothers Days, Cabotage Day, Feast etc. These posts are classified under the first category which is "special days". $76 \%$ of the posts involve in corporate image of the company. These posts cover previous experiences, works on progress, in-firm promotions, advertisements or companies are in and open positions in the company, so these posts are collected under the "announcements" category.

Although number of followers per company is 5466, average number of posts are only 59 and average number of comments made by followers are 38 which means every 66 posts take comments out of 100 posts. As seen in Table 2 average number of likes per company reaches to 5487 which is quite same with the number of followers. Finally, average number of the shared posts per company is 35 in the same period. It also reveals that from the statistics the order of top five companies according to number of followers and number of likes are quite similar. Number of Posts and Number of Liked posts are almost 
Table 2. Social Media Statistics of Maritime Companies

\begin{tabular}{|c|c|c|c|c|c|c|c|c|}
\hline & $\begin{array}{l}\text { Followers } \\
\text { (n) }\end{array}$ & $\begin{array}{l}\text { Posts } \\
\text { (n) }\end{array}$ & $\begin{array}{c}\text { Liked } \\
\text { Posts } \\
\text { (n) }\end{array}$ & $\begin{array}{l}\text { Comments } \\
\text { (n) }\end{array}$ & $\begin{array}{c}\text { Commented } \\
\text { Posts (n) }\end{array}$ & $\begin{array}{l}\text { Likes } \\
\text { (Total) } \\
\text { (n) }\end{array}$ & $\begin{array}{l}\text { Shares } \\
\text { (n) }\end{array}$ & $\begin{array}{l}\text { Shared } \\
\text { Posts } \\
\text { (n) }\end{array}$ \\
\hline Altun Lojistik Aş. & 504 & 29 & 29 & 10 & 5 & 501 & 12 & 8 \\
\hline $\begin{array}{l}\text { Batu International } \\
\text { Lojistik }\end{array}$ & 6.414 & 15 & 15 & 1 & 1 & 6.687 & 13 & 13 \\
\hline Borusan Lojistik & 24.098 & 110 & 110 & 62 & 39 & 24.025 & 319 & 90 \\
\hline $\begin{array}{l}\text { DSL Lojistik ve } \\
\text { Uluslararası } \\
\text { Taşımacılık }\end{array}$ & 266 & 6 & 6 & 0 & 1 & 283 & 0 & 0 \\
\hline Fevzi Gandır Lojistik & 1.119 & 81 & 81 & 17 & 11 & 1102 & 71 & 52 \\
\hline $\begin{array}{l}\text { Galata Taşımacılık } \\
\text { ve Tic. }\end{array}$ & 2.764 & 53 & 53 & 12 & 6 & 2.777 & 48 & 44 \\
\hline $\begin{array}{l}\text { Gezairi Transport } \\
\text { Nak. Ve Tic. }\end{array}$ & 2.076 & 10 & 10 & 36 & 10 & 2.081 & 90 & 10 \\
\hline $\begin{array}{l}\text { Globelink Ünimar } \\
\text { Lojistik }\end{array}$ & 1.738 & 61 & 61 & 7 & 4 & 1.734 & 22 & 19 \\
\hline $\begin{array}{l}\text { Hilal Trans } \\
\text { Uluslararası Nak. } \\
\text { ve Tic. }\end{array}$ & 28.262 & 19 & 19 & 9 & 6 & 28.441 & 15 & 9 \\
\hline $\begin{array}{l}\text { IMS Lojistik } \\
\text { Uluslararası Taş. }\end{array}$ & 1.177 & 20 & 20 & 6 & 3 & 1.185 & 6 & 5 \\
\hline Logitrans Lojistik & 838 & 165 & 165 & 21 & 7 & 828 & 135 & 79 \\
\hline $\begin{array}{l}\text { MTS Uluslararası } \\
\text { Taş.ve Tic. }\end{array}$ & 354 & 9 & 9 & 4 & 2 & 356 & 10 & 6 \\
\hline $\begin{array}{l}\text { Sarp Intermodal } \\
\text { Hiz.İç ve Dıș Tic. }\end{array}$ & 118 & 57 & 57 & 3 & 3 & 115 & 21 & 11 \\
\hline $\begin{array}{l}\text { DB Schenker Arkas } \\
\text { Nak.ve Tic. }\end{array}$ & 10.317 & 120 & 120 & 283 & 76 & 10.248 & 3.141 & 73 \\
\hline $\begin{array}{l}\text { Sertrans } \\
\text { Uluslararası Nak. } \\
\text { Tic. }\end{array}$ & 1.958 & 121 & 121 & 100 & 85 & 1.956 & 90 & 100 \\
\hline
\end{tabular}

same. Number of liked posts are nearly 4 times more than number of commented posts. Number of comments and number of shared posts are almost equal.

How many times posts are re-shared by followers are also examined under these four categories; special days, corporate image, sectoral news and announcements. It has shown that special days posts were re-shared 763 times, corporate image posts 3093 times, sectoral news posts 55 times and announcements 183 times by followers in total.
In Table 3 number of shares for each category are reported. It's obviously seen that posts about corporate image are shared by followers in a large extent. Additionally, in Borusan's page 90 posts were published and 280 people re-shared this post. Similarly, Gezairi published 10 posts but the posts related to corporate image were reshared by 48 people. DB Schenkler has 73 posts in total and posts regarding corporate image were re-shared by 2499 individuals.

When the contents of the posts under these four categories are examined 
Table 3. Number of Re-shared Posts Per Category

\begin{tabular}{|c|c|c|c|c|c|}
\hline \multirow{2}{*}{$\begin{array}{l}\text { Number of Shares for Each } \\
\text { Category } \\
\text { Company }\end{array}$} & \multicolumn{4}{|c|}{ Content of Posts } & \multirow[b]{2}{*}{$\begin{array}{l}\text { Number of } \\
\text { Shared Posts }\end{array}$} \\
\hline & Special Days & $\begin{array}{l}\text { Corporate } \\
\text { Image }\end{array}$ & $\begin{array}{l}\text { Sectoral } \\
\text { News }\end{array}$ & Announcements & \\
\hline Altun Lojistik Aș. & 5 & 7 & 0 & 0 & 8 \\
\hline Batu International Lojistik & 9 & 1 & 0 & 3 & 13 \\
\hline Borusan Lojistik & 101 & 280 & 12 & 27 & 90 \\
\hline $\begin{array}{l}\text { DSL Lojistik ve Uluslararası } \\
\text { Taşımacılık }\end{array}$ & 0 & 0 & 0 & 0 & 0 \\
\hline Fevzi Gandır Lojistik & 20 & 43 & 0 & 8 & 52 \\
\hline Galata Taşımacılık ve Tic. & 22 & 26 & 0 & 0 & 44 \\
\hline $\begin{array}{l}\text { Gezairi Transport Nak. Ve } \\
\text { Tic. }\end{array}$ & 27 & 48 & 15 & 0 & 10 \\
\hline Globelink Ünimar Lojistik & 3 & 14 & 2 & 3 & 19 \\
\hline $\begin{array}{l}\text { Hilal Trans Uluslararası } \\
\text { Nak.ve Tic. }\end{array}$ & 1 & 14 & 0 & 0 & 9 \\
\hline $\begin{array}{l}\text { IMS Lojistik Uluslararası } \\
\text { Taş. }\end{array}$ & 4 & 2 & 0 & 0 & 5 \\
\hline Logitrans Lojistik & 19 & 108 & 0 & 8 & 79 \\
\hline $\begin{array}{l}\text { MTS Uluslararası Taş.ve } \\
\text { Tic. }\end{array}$ & 3 & 4 & 0 & 3 & 6 \\
\hline $\begin{array}{l}\text { Sarp Intermodal Hiz.İç ve } \\
\text { Diș Tic. }\end{array}$ & 3 & 17 & 0 & 1 & 11 \\
\hline $\begin{array}{l}\text { DB Schenker Arkas Nak. } \\
\text { ve Tic. }\end{array}$ & 501 & 2.499 & 26 & 115 & 73 \\
\hline $\begin{array}{l}\text { Sertrans Uluslararası Nak. } \\
\text { Tic. }\end{array}$ & 45 & 30 & 0 & 15 & 100 \\
\hline Average & 55 & 220 & 14 & 20 & 35 \\
\hline
\end{tabular}

following issues are noted;

- Most shared posts by followers under the category of "corporate image" are; work processes, new equipment, ships or new ports and new routes.

- Second most shared posts by followers under the category of "corporate image" are the posts related to staff and their success or promotions, in particular the posts tagged with specific names.

- Most shared posts by followers under the category of "special days" are the posts related to celebrations (national holidays, religious holidays and memorial days and cabotage day etc.)
These posts are shared by followers to a large extent if the posts have no or very small logo on them.

- According to the media of the posts it is obviously seen that videos are much more shared by followers than photos.

- In special days category it is remarkably seen that the posts on celebrations are shared by followers to a large extent if the posts have no logo on them.

Additionally, metrics for stakeholder engagement levels are calculated and listed in Table 4. Top three companies according to their engagements level are Borusan, Logitrans and Galata respectively. 
Table 4. Customer Engagement Levels

\begin{tabular}{|l|c|c|c|c|c|c|c|c|c|c|}
\hline Company & P1 & P2 & P3 & C1 & C2 & C3 & V1 & V2 & V3 & E \\
\hline Altun Lojistik A.Ş. & 1 & 445.80 & 69.50 & 0.87 & 0.07 & 0.01 & 0.87 & 0.87 & 0.14 & 70 \\
\hline Batu International Lojistik & 1 & 218.41 & 9.06 & 0.82 & 0.56 & 0.02 & 0.82 & 2.90 & 0.12 & 9 \\
\hline Borusan Lojistik & 1 & 47.17 & 177.32 & 0.00 & 0.00 & 0.00 & 0.00 & 0.00 & 0.00 & 177 \\
\hline $\begin{array}{l}\text { DSL Lojistik ve Uluslararası } \\
\text { Taşımacılık }\end{array}$ & 1 & 13.60 & 12.16 & 0.64 & 0.21 & 0.19 & 0.64 & 0.88 & 0.78 & 13 \\
\hline Fevzi Gandur Lojistik & 1 & 52.40 & 18.96 & 0.83 & 0.23 & 0.08 & 0.83 & 0.91 & 0.33 & 19 \\
\hline Galata Taşımacılık ve Ticaret & 1 & 208.10 & 100.24 & 1.00 & 3.60 & 1.73 & 1.00 & 9.00 & 4.34 & 106 \\
\hline $\begin{array}{l}\text { Gezairi Transport Nakliyat ve } \\
\text { Ticaret }\end{array}$ & 1 & 28.43 & 16.36 & 0.31 & 0.11 & 0.07 & 0.31 & 0.36 & 0.21 & 17 \\
\hline Globelink Ünimar Lojistik & 1 & 1496.89 & 52.96 & 0.47 & 0.47 & 0.02 & 0.47 & 0.79 & 0.03 & 53 \\
\hline $\begin{array}{l}\text { Hilal Trans Uluslararası Nakliyat } \\
\text { ve Tic. }\end{array}$ & 1 & 59.25 & 50.34 & 0.25 & 0.30 & 0.25 & 0.25 & 0.30 & 0.25 & 51 \\
\hline $\begin{array}{l}\text { İMS Lojistik Uluslararası } \\
\text { Taşımacılık }\end{array}$ & 1 & 5.02 & 5.99 & 0.48 & 0.13 & 0.15 & 0.48 & 0.82 & 0.98 & 7 \\
\hline Logitrans Lojistik & 1 & 39.56 & 111.74 & 0.67 & 0.44 & 1.26 & 0.67 & 1.11 & 3.14 & 116 \\
\hline $\begin{array}{l}\text { MTS Uluslararası Taşımacıllk } \\
\text { ve Tic. }\end{array}$ & 1 & 2.02 & 17.10 & 0.19 & 0.05 & 0.45 & 0.19 & 0.37 & 3.12 & 21 \\
\hline $\begin{array}{l}\text { Sarp Intermodal Hizmetleri İç ve } \\
\text { Diş Tic. }\end{array}$ & 1 & 85.40 & 8.28 & 0.61 & 2.36 & 0.23 & 0.61 & 26.18 & 2.54 & 11 \\
\hline $\begin{array}{l}\text { DB Schenker Arkas Nakliyat ve } \\
\text { Ticaret }\end{array}$ & 1 & 16.17 & 8.26 & 0.83 & 0.83 & 0.42 & 0.83 & 0.74 & 0.38 & 9 \\
\hline $\begin{array}{l}\text { Sertrans Uluslararası Nakliyat } \\
\text { Ticaret }\end{array}$ & 1 & 194.00 & 46.00 & 0.55 & 0.65 & 0.37 & 0.55 & 3.04 & 1.14 & 48 \\
\hline
\end{tabular}

Top three companies according to their engagements level are Borusan, Logitrans and Galata respectively.

\section{Conclusion and Implications}

B2C companies are using social media broadly when compared with B2B (business-to-business) companies. B2C companies use social media effectively to promote their brands and increase the number of fans. For that reason, customers can easily interact with other followers and with brand by using social media. On the other hand, B2B online communities are quite new. Such communities can professionally upload content and achieve collaboration with the stakeholders. It is known that B2B social media spending increased 46 percent yearly [32]. However, this amount might vary sector by sector.
In this study, exploratory research design was conducted to gain some insights on Facebook usage patterns of maritime businesses. Through content analysis, all the maritime businesses existing in Facebook were investigated in terms of the frequency and content of posts, comments and shares. Bonson and Ratkai 's (2013) social engagement metrics were used in order to calculate social media engagement. These metrics provide an insight to understand and measure social media usage of companies on Facebook [30]. In this research this metrics were applied for the first time to maritime transportation companies existing on Facebook.

According to the results of the analysis some essential issues are determined. First, this study confirms that Turkish maritime industry is not active on social 
media yet. Posts shared by companies are related to corporate image in a large extent. These posts consist of previous experiences, works on progress, in-firm promotions, advertisements or news about the company or employees, success stories and social responsibility projects. Posts on special days and celebrations follow the first category in a considerable extent. These findings show similarity with the findings of Çalışkan and Esmer [1]. They found that the main difference between Turkish and World port samples is the given importance on the celebration of special days (e.g., the celebration of festivals, special days such as Victory Day and Republic Day).

Secondly, from the engagement perspective it reveals that number of posts and number of liked posts are almost same. Number of liked posts are nearly 4 times more than number of commented posts. Number of comments and number of shared posts are almost equal. In line with the frequencies of posts according to their contents, corporate image posts are shared substantially, posts on special days and celebrations follow it, considerably.

Thirdly, posts with highest engagement average are the posts under the category of "corporate image" are on work processes, new equipment, ships or new ports and new routes, staff and their success or promotion. It seems that if the posts are tagged with specific names they are most likely shared by staff.

In special days category it is remarkably seen that the posts on celebrations are shared by followers to a large extent if the posts have no logo or have a small logo on them. Additionally, according to the media of the posts it is obviously seen that videos are much more shared by followers than photos.

Finally, for logistic companies average stakeholder engagement index was found 52 by Sürücü and Sakar in 2017 [27]. However, in the present study this index is found 18 for maritime transportation companies. It shows that maritime industry has a very small share in logistic sector in terms of social media usage efficiency.

For practical implication, maritime companies are suggested to be taken the advantage of Facebook accounts in the following issues; firstly, Facebook is the social network platform with more than 2 billion active users [33] interact with each other and organizations. Facebook is able to be used efficiently for updating schedules in real time, sharing the conditions that may negatively affect the delivery and sharing the resources (equipment, technology, software, staff etc.) of the company to emphasize corporate image as well. According to Andzulis etal. (2012) B2B companies should focus on developing long-term relationships rather than building short-term exchanges. Thus, maritime practitioners may utilize Facebook to build long-term relationship with their stakeholders. This will facilitate the process of communicating versatile messages to them. Being responsive, building trust, increased positive reputation and credibility $[34,35,36]$ can be gained by sharing contents, photos and videos through Facebook.

This study should be considered under some limitations. As the number of the sample is only fifteen, a quantitative analysis couldn't be conducted to analyse the relationship between content type and engagement statistics. Forming the sample with posts instead of companies would provide a broader sample and future studies might investigate whether there is a relationship between and content type and stakeholder engagement level by quantitative research design. Commitment measure was calculated as the sum of all comments, yet it can be improved by separating positive and negative comments. Furthermore, content analysis can be repeated for other social media tools such as Twitter, Instagram and Linkedin. 


\section{References}

[1] Çalışkan A. and Esmer S. (2018). Social Media Usage Patterns in Port Industry: Implications for Port Promotion and Public Relations, Journal of ETA Maritime Science, 6(1):61-74.

[2] Kho, N. (2008). B2B gets social media. EContent, 31(3): 26- 30.

[3] Social media (2018). Fishbat. Date of access: 02.10.2018 https://fishbat. com/services/social-media-agency/

[4] Mangold, W. G. and Faulds, D. J. (2009). Social media: The new hybrid element of the promotion mix. Business Horizons, 52(4):357-365.

[5] United Nations Conference on Trade and Development (2017). Review of Maritime Transport 2017. Date of access: 02.10.2018, https://unctad. org/

[6] Fafaliou, I., Lekakou, M. and Theotokas, I.(2006). Is the European shipping industry aware of corporate social responsibility? The case of the Greekowned short sea shipping companies. Marine Policy, 30 (4):412-419.

[7] Hearn, G., Foth and M, Gray,H. (2009). Applications and implementations of new media in corporate communications: An action research approach.CorporateCommunications: An International Journal, 14(1):49-61.

[8] Page, R., Barton, D., Unger, J.W. and Zappavigna M. (2014). Researching language and social media: A student guide. Routledge.

[9] Järvinen, J., Tollinen, A., Karjaluoto, H. and Jayawardhena, C. (2012). Digital and social media marketing usage in B2B industrial section. Marketing Management Journal, 22(2):102-117.

[10] Swani, K., Brown, B. P. and Milne, G. R. (2014). Should Tweets Differ for B2B and B2C? An Analysis of Fortune 500 Companies' Twitter Communications. Industrial Marketing Management, 43 (5):873-881.
[11] Michaelidou, N., Siamagka, N. T., and Christodoulides, G. (2011). Usage, barriers and measurement of social media marketing: An Exploratory Investigation Of Small And Medium B2B Brands. Industrial Marketing Management, 40(7):1153-1159.

[12] North Venture Partners, (2009) Nine Ways Your Business Could Be Using Social Media, But Probably Isn't. Brandchannel. Retrieved January 22, 2011, from http://www. brandchannel. com/images/papers/ 460_Nine_Ways.pdf.

[13] Katona Z. and Sarvary M. (2014). Berkeley-Haas Case Series Maersk Line: B2B Social Media- It's Communication, Not Marketing. California Management Review, 56(3):142-156.

[14] Huotari, L., Ulkuniemi, P., Saraniemi, S. and Mäläskä, M. (2015). Analysis Of Content Creation İn Social Media By B2B Companies. Journal of Business \& Industrial Marketing, 30 (6):761770 .

[15] Walters, P. G. (2008). Adding Value In Global B2B Supply Chains: Strategic Directions And The Role of The Internet As A Driver Of Competitive Advantage. Industrial Marketing Management, 37(1):59-68.

[16] Gupta, S., Balmer, J. M. T. and Low, B. (2015). Brands In, From And To Emerging Markets: The Role of Industrial Relationships. Industrial Marketing Management, 51: 4-10.

[17] Brennan, R. and Croft, R. (2012). The Use Of Social Media In B2B Marketing And Branding: An Exploratory Study. Journal of Consumer Behaviour, 11(2):101-115.

[18] Mehmet,Mand Clarke,R.J.(2016).B2B Social Media Semantics: Analysing Multimodal Online Meanings In Marketing Conversations. Industrial Marketing Management 54:92-106. 
[19] Siamagka, N.-T., Christodoulides, G., Michaelidou, and N., Valvi, A. (2015). Determinants Of Social Media Adoption By B2B Organizations. Industrial Marketing Management 51: 89-99.

[20] Andersson,S. and Wikström,N. (2017). Why And How Are Social Media Used In A B2B Context, And Which Stakeholders Are Involved?. Journal of Business \& Industrial Marketing, 32(8):1098-1108.

[21] Valos,M., Polonsky,J. Mavondo, M and Lipscomb, J. (2015). Senior Marketers' Insights Into The Challenges Of Social Media Implementation In Large Organisations: Assessing Generic And Electronic Orientation Models As Potential Solutions. Journal of Marketing Management, 31 (7-8) :713-746.

[22] Ferrell, O. C., Gonzalez-Padron, T. L., Hult, G. T. M. and Maignan, I. (2010). From Market Orientation To Stakeholder Orientation. Journal of Public Policy and Marketing, 29(1):93-96.

[23] Bruce, P., and Shelley, R. (2010). Assessing Stakeholder Engagement. Communication Journal of New Zealand, 11:30-48.

[24] Kuvykaite R. and Piligrimi, Z. (2013). Communication In Social Media For Company's Image Formation. Economics and Management. 18 (2):305-317.

[25] Gorry, G.A. and Westbrook, R.A. (2011). Can You Hear Me Now? Learning From Customer Stories. Business Horizons, 54(6):575-584.

[26] Manetti, G., Bellucci, M. and Bagnoli, L. (2016). Stakeholder Engagement and Public Information Through Social Media: A Study of Canadian and American Public Transportation Agencies, American Review of Public Administration, 47(8):991-1009.
[27] Sürücü, E. and Denktaş-Şakar, G. (2018). Sosyal Medya Araciliğiyla Paydaş Katiliminin Ölçülmesi: Türk Lojistik Hizmet Sağlayan İşletmeler Üzerine Bir İnceleme, Dumlupınar Üniversitesi Sosyal Bilimler Dergisi, 8 :107-129.

[28] Metushi E., Fradeani A. (2019). Company Reporting on Social Media: A Content Analysis of the Albanian Companies. In: Lazazzara A., Nacamulli R., Rossignoli C., Za S. (eds) Organizing for Digital Innovation. Lecture Notes in Information Systems and Organisation, Vol 27. Springer, Cham.

[29] Hsieh, H.-F. and Shannon, S. E. (2005). Three Approaches to Qualitative Content Analysis. Qualitative Health Research, 15(9):1277-1288.

[30] Bonsón, E., and Ratkai, M. (2013). A Set Of Metrics To Assess Stakeholder Engagement And Social Legitimacy On A Corporate Facebook Page. Online Information Review, 37(5):787-803.

[31] Ralphs, M. (2011). Built In Or Bolt On: Why Social Currency Is Essential To Social Media Marketing. Journal of Direct, Data and Digital Marketing Practice, 12 (3):211-215.

[32] https://www.b2bmarketing.net/en$\mathrm{gb} /$ resources/news/social-media-adspend-increase-235-billion-202. Date of access: 05.10.2018

[33] Nowak,M.,and Spiller,G.(2017). Two billion people coming together on Facebook. Retrieved from https:// newsroom.fb.com/news/2017/06/ two-billion-people-coming-togetheron-facebook/ Date of access: 26.03.2019

[34] Agnihotri, R., Kothandaraman, P., Kashyap, R., and Singh, R. (2012). Bringing "Social" Into Sales: The Impact Of Salespeople's Social Media Use On Service Behaviors And Value Creation. Journal of Personal Selling \& Sales Management, 32(3):333-348. 
[35] Andzulis, J., Panagopoulos, N., and Rapp, A. (2012). A Review Of Social Media And Implications For The Sales Process. Journal of Personal Selling \& Sales Management, 32(3):305-316.

[36] Lacoste, S. (2016). Perspectives On Social Media And Its Use By Key Account Managers. Industrial Marketing Management, 54:33-43. 